\title{
A feedback loop that regulates the expression of polycomb group protein Suz12 via non-canonical WNT signaling pathway in blast crisis of chronic myeloid leukemia
}

\author{
Jaime Cofre $^{1 *}$ and Eliana Abdelhay ${ }^{2}$
}

*Correspondence: jaime.cofre@ufsc.br

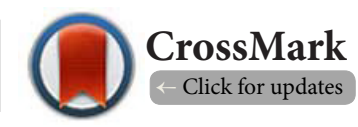

${ }^{1}$ Embryology Laboratory of Molecular and Cancer, Federal University of Santa Catarina, CEP 88040-900, Florianópolis, SC, Brazil. ${ }^{2}$ Division of Laboratories of CEMO, National Cancer Institute, Rio de Janeiro, Brazil.

\begin{abstract}
The importance of Kaiso, Wnt5, Wnt1 1 and PcG proteins in tumorigenesis has been widely discussed in the scientific literature, in recent years. However, until now, there has been no exploration of the relationship of these sets of proteins and their meaning in vital processes of embryogenesis such as gastrulation or events that trigger cancer. In this paper, we characterize an independent transcriptional regulation of repression by Suz12 on Kaiso expression. The functional block of Suz12 by small interfering RNA produced an almost complete depletion of Kaiso expression in K562 cells. We suggest a regulatory loop that could involve a positive regulation of Suz12 on Kaiso and Wnt5a/Wnt1 1 on Suz12, and also, a negative regulation of Kaiso on Wnt1 1 establishing an important regulatory feedback to the normal state of the cell. The rupture of that regulatory balance might result in the tumor establishment. The close relation of Suz12 and non-canonical pathways of Wnt may provoke significant implications for future therapeutic strategies in chronic myeloid leukemia.
\end{abstract}

Keywords: Polycomb group proteins, kaiso, chronic myeloid leukemia, K562 cells

\section{Introduction}

The polycomb group (PcG) proteins act as a global silencer of gene expression, and they are highly conserved from drosophila to humans [18]. The PcG proteins are required for the correct spatial and temporal expression of Hox genes during embryonic development and are also implicated in diverse cellular processes such as, for example, the X-chromosome inactivation, cell fate decisions, cell cycle progression, stem cells differentiation and senescence [19]. PcG proteins form large multimeric complexes defined as polycomb repressive complex (PRC) and they are classically subdivided into three groups: PRC1, PRC2 and PhoRC [4]. The components of PRC2 complex are the enhancer of zeste homolog 2 (EZH2), ectodermic embryonic development (EED), suppressor of zeste 12 (SUZ12) and retinoblastoma-associated protein 46 (RbAp46) [4]. EZH2 has the catalytic subunit of the complex with histone methyltransferase activity, whereas SUZ12 critically regulates the complex PRC2 activity $[2,11]$.

The role played by PcG proteins is of particular importance in the cellular fate-determining process and its implication in tumorigenesis. Thus, the abnormal PcG expression leads to a loss of cell identity, improves a proliferative ability and increases the migratory/invasive potential. These proteins are often aberrantly expressed in cancer cells and, in particular, Suz12, EZH2 and BMI1 are well known to be over-expressed in a certain number of human tumors including breast cancer, prostate cancer and chronic myeloid leukemia $[5,6,9,10,15,20]$. The principal mechanism by which PcG proteins promote tumorigenesis and metastasis seems to be senescence bypass $[1,8]$ and increase cell survival $[6,7]$. Recent studies have shown that PcG proteins may also regulate cellular and oncogenic functions in a transcription repression-independent manner. These functions may be termed the non-classical-Polycombfunctions of PcG proteins [19].

Despite the many studies showing the participation of Kaiso and Suz 12 in tumorigenesis, there is no evidence linking these two proteins in cancer processes, in the literature. In the present work and for the first time, there is a direct regulation of Suz12 over Kaiso in a non-classic manner of involving a transcriptional regulation independent of repression. The blocking of Suz12

(C) 2017 Cofre et al; licensee Herbert Publications Ltd. This is an Open Access article distributed under the terms of Creative Commons Attribution License 
Cofre et al. Hematology and Leukemia 2017,

http://www.hoajonline.com/journals/pdf/2052-434X-5-1.pdf

doi: 10.7243/2052-434X-5-1

by siRNA produced a complete removal of Kaiso expression. We discuss future therapeutic implications in connection with chronic myeloid leukemia.

\section{Materials and methods \\ Cell line}

K562 cell line was maintained in RPMI 1640 medium supplemented with $10 \%$ foetal bovine serum (Hyclone), $100 \mathrm{U} / \mathrm{ml}$ penicillin (Invitrogen), $100 \mathrm{mg} / \mathrm{mL}$ streptomycin (Invitrogen) at $37^{\circ} \mathrm{C}$ in $5 \% \mathrm{CO} 2 . \mathrm{K} 562$, established from a CML patient in blast crisis [13], was used as a BCR-ABL-positive cell line.

\section{RNAi knockdown and transfection}

All RNA oligonucleotides described in this study were synthesized and purified using highperformance liquid chromatography (HPLC) at Integrated DNA Technologies (Coralville, lowa), and the duplex siRNAs for Suz 12 are: sense GCAAGAGAUGACCUGCAUU and antisense AAUGCAGGUCAUCUCUUGC (Target sequence 5'-GCAAGAGATGACCTGCATT-3'). RNAi knockdown and transfections were performed following the manufacturer's protocols of the TriFECTa Dicer-Substrate RNAi kit (Integrated DNA Technologies, Coralville, IA). K562 cells $\left(1 \times 10^{6}\right.$ cells per well) were split in 24 -well plates to $60 \%$ confluency in RPMI media 1 day prior to transfection. The TriFECTa kit contains control sequences for RNAi experiments which include a fluorescent-labeled transfection control duplex and a scrambled universal negative control RNA duplex that is absent in human, mouse, and rat genomes. Fluorescence microscopy and FACS monitored the transfection efficiency according to the manufacturer's recommendations. Only experiments in which transfection efficiencies were $\geq 90 \%$ were evaluated. RNA levels were measured $36 \mathrm{~h}$ after transfection. All duplexes used were evaluated at 25 and $10 \mathrm{nM}$. All transfections were minimally performed in triplicate, and the data were averaged.

\section{Real time PCR}

QRT-PCR Analysis Quantitation of Kaiso RNA transcript was carried out by real time PCR (QRT-PCR). For expression of Kaiso we used forward primer $5^{\prime}$-AAGCTTTATCGTTTACATCCAT-3' and reverse primer 5'-ATACCCAATACCATCATCCTT-3'. Expression of the housekeeping gene $\beta$-actin was used to normalize mRNA expression. Two micrograms of total RNA from K562 cell line or transfected K562 cell line, were reverse transcripted with Superscript III Reverse transcriptaseVR (Invitrogen). cDNAs were mixed with SYBR Green PCR Master MixVR (Applied Biosystems) and specific primers. Real time PCR was performed in an $A B I$ Prism 7000 thermocycler (Applied Biosystems), with 50 cycles of $15 \mathrm{sec}$ at $95^{\circ} \mathrm{C}$ and $2 \mathrm{~min}$ at $68^{\circ} \mathrm{C}$. Expression levels were estimated in triplicate with specific and control primers. For each sample, the relative amounts of transcripts of the target gene and the internal control were estimated from a standard curve. Results were expressed in arbitrary units as the ratio of the target gene transcript/internal transcript (data represented by average $\pm S D$ of three measurements).

\section{Statistical analysis}

Data were expressed as means \pm standard deviation (SD). The significance differences between control and treated groups was evaluated using one-way analysis of variance (ANOVA). Experimental tests were performed at least three times. Differences were considered to be significant when $\mathrm{P}<0.05$.

\section{Results}

One of the mechanisms clearly recognized by which PcG proteins promote tumorigenesis is the increase in cell survival [6]. As it was previously reported, the RNAi knock-down of Kaiso in K562 cells improves survival and proliferation [3]. On the other hand, we know that the expression of Suz12 is significantly increased in various types of cancer [15]. Therefore, we decided to evaluate the existence of a transcriptional regulation independent of repression of Suz 12 over Kaiso. Given that Kaiso is expressed in $\mathrm{K} 562$ cells, this study set out to examine how loss of Suz12 might affect the gene expression of Kaiso. To inactivate Suz12 we employed siRNA (Figure 1a) as described

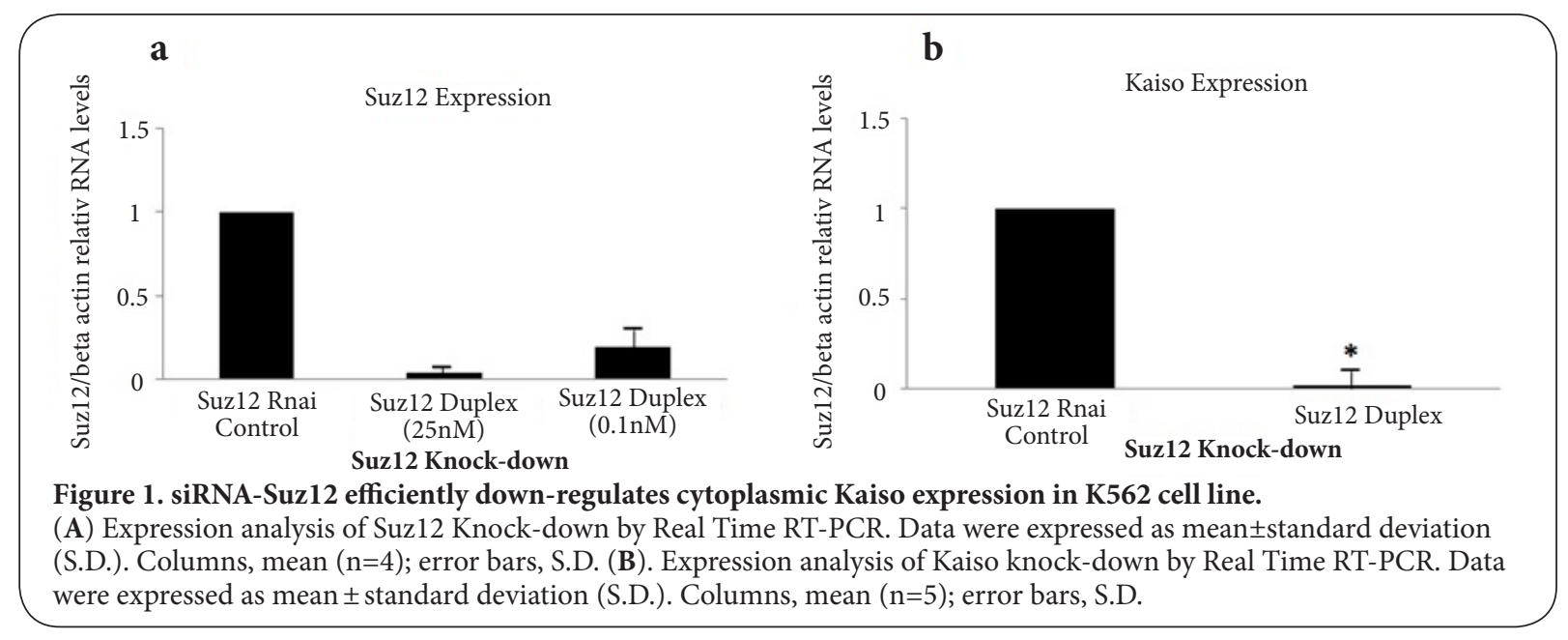


in the materials and methods. We developed a transfection protocol that led to over $96 \%$ of the K562 cells taking up the siRNA. Next, the effectiveness of the knockdown was assessed using QRT-PCR. The analysis showed that Kaiso mRNA levels were decreased by $98 \%$ (Figure 1 b) in $\mathrm{K} 562$ cells transfected by siRNA-Suz12 ( $25 \mathrm{nM}$ for $24 \mathrm{~h}$ ), when compared to scrambled knock-down cells (Suz12 RNAi control). Using siRNA-Suz12 ( $10 \mathrm{nM}$ for $24 \mathrm{~h}$ ) a reduction of $95 \%$ in Kaiso was achieved when compared to scrambled knockdown cells by QRT-PCR analysis (data not shown).

\section{Discussion}

Previously Pizzatti et al., reported that both Wnt5a and Wnt11 upregulate the expression of Suz 12 by acting as transcription factors in the cell nucleus [15] (Figure 2a). The real importance of that positive regulation should be understood in the context of leukemia patients who present, in the blast phase, a significant increase in the expression of Suz12. From our point of view, it suggests that Wnt5a and Wnt11 should be increased in the context of patients who enter that stage of the disease and always results in a worsening of their clinical condition. On the other hand, Wnt11 is one of several $\beta$-catenin/ TCF target genes that also contain a putative Kaiso-binding site in its promoter region, suggesting that Kaiso and TCF/ LEF cooperate to repress Wnt11 transcription [14] (Figure 2c). Besides, the present research has shown that knock-down of Suz12 by small interfering RNA (siRNA) produces a significant decrease of $98 \%$ in the expression of Kaiso in K562 cells, the first established human immortalized myelogenous leukemia line [13]. Evidence presented above suggests that, at least,

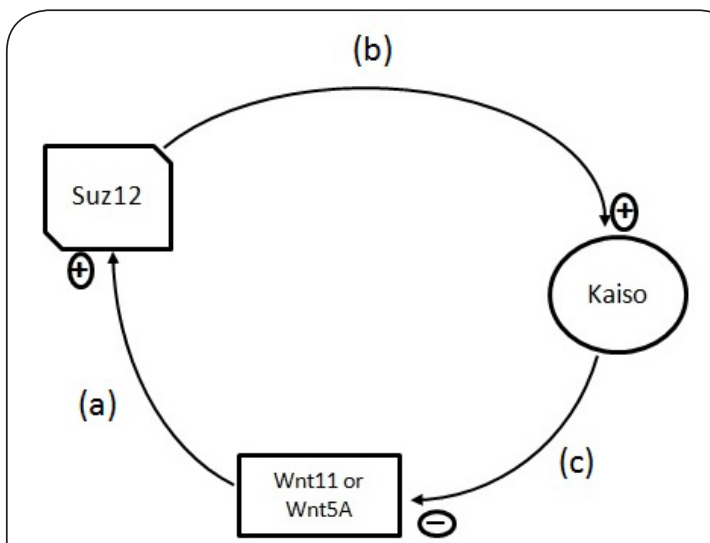

Figure 2. Regulatory loop among Kaiso, Wnt11/5a and Suz12.

(a). The genes Wnt11 and Wnt5a up-regulate Suz12 expression (supressor of zeste 12) acting in the nucleus as transcriptional factors, as described previously by [15]. (b) Suz12 activates the transcription of Kaiso, as described here in this article and (c) Kaiso and TCF/LEF cooperate to repress the transcription of Wnt11 as described by [14]. in the context of a human erythroleukemic cell line, there is a positive regulatory effect of Suz 12 on Kaiso. It remains the doubt if it may be extended to include the gastrulation, and as a general rule, all the embryonic processes (Figure $\mathbf{2 b}$ ). Although it seems inconsistent with the well-established silencing function of PRC complexes, the knockdown of EZH2 by siRNA produced a significant decrease, rather than increase, of G1/S-expressed cyclins [1]. It suggests that PRC2 complex may play an activation role of gene expression through an uncharacterized independent domain instead of the previously reported repressor domain $[12,16]$.

This regulatory loop may be extremely crucial in controlling cellular homeostasis where the levels of Suz12, Wnt11 and Kaiso can be properly maintained during embryogenesis (gastrulation) or during the normal state of cells in adult tissue. Some changes in the regulatory loop may produce significant consequences for the development, for example, of chronic myeloid leukemia as the subcellular localization of Kaiso is susceptible to microenvironmental alterations of the cell [17]. Thus, we imagine that Kaiso's displacement from the nucleus to the cytoplasmic compartment [3], thereby breaking the normal regulatory loop equilibrium could be responsible for triggering the super expression of Wnt $5 \mathrm{a} / \mathrm{Wnt} 11$, and consequently, the overexpression of Suz 12 in the context of that cell set. Consistent with the rupture of regulatory loop equilibrium the PcG proteins overexpression seems to be a trademark for some types of tumors $[5,6,9,10,20]$. Particularly, the increase of Suz 12 is one of the main features found in K562 cells used as the cellular model of chronic myeloid leukemia in a blast crisis [15]. Therefore, this epigenetic regulatory loop can have profound implications for future therapeutic strategies not only in chronic myeloid leukemia but also in other tumor types.

\section{Competing interests}

The authors declare that they have no competing interests.

Authors' contributions

\begin{tabular}{|l|c|c|}
\hline Authors' contributions & JC & EA \\
\hline Research concept and design & $\checkmark$ & $\checkmark$ \\
\hline Collection and/or assembly of data & $\checkmark$ & -- \\
\hline Data analysis and interpretation & $\checkmark$ & -- \\
\hline Writing the article & $\checkmark$ & -- \\
\hline Critical revision of the article & $\checkmark$ & $\checkmark$ \\
\hline Final approval of article & $\checkmark$ & $\checkmark$ \\
\hline Statistical analysis & $\checkmark$ & -- \\
\hline
\end{tabular}

\section{Acknowledgement}

The study was supported by Brazilian National Cancer Institute (INCA of Rio de Janeiro) and Instituto de Diagnóstico e Anatomia Patológica (IDAP Itda) through the covenant term 2012/0045.

\section{Publication history}

Editor: Dongqing Yan, University of Utah, USA.

EIC: Evangelos Terpos, University of Athens School of Medicine, Greece. Received: 29-Sep-2016 Final Revised: 10-Dec-2016

Accepted: 30-Dec-2016 Published: 07-Jan-2017 
Cofre et al. Hematology and Leukemia 2017,

http://www.hoajonline.com/journals/pdf/2052-434X-5-1.pdf

doi: 10.7243/2052-434X-5-1

\section{References}

1. Bracken AP, Pasini D, Capra M, Prosperini E, Colli E and Helin K. EZH2 is downstream of the pRB-E2F pathway, essential for proliferation and amplified in cancer. EMBO J. 2003; 22:5323-35. | Article | PubMed Abstract | PubMed FullText

2. Cao R and Zhang Y. SUZ12 is required for both the histone methyltransferase activity and the silencing function of the EED-EZH2 complex. Mol Cell. 2004; 15:57-67. | Article | PubMed

3. Cofre J, Menezes JR, Pizzatti L and Abdelhay E. Knock-down of Kaiso induces proliferation and blocks granulocytic differentiation in blast crisis of chronic myeloid leukemia. Cancer Cell Int. 2012; 12:28. | Article | PubMed Abstract | PubMed FullText

4. Geisler SJ and Paro R. Trithorax and Polycomb group-dependent regulation: a tale of opposing activities. Development. 2015; 142:287687. | Article | PubMed

5. Glinsky GV, Berezovska $O$ and Glinskii AB. Microarray analysis identifies a death-from-cancer signature predicting therapy failure in patients with multiple types of cancer. J Clin Invest. 2005; 115:1503-21. | Article | PubMed Abstract | PubMed FullText

6. Guo WJ, Zeng MS, Yadav A, Song LB, Guo BH, Band V and Dimri GP. Mel-18 acts as a tumor suppressor by repressing Bmi-1 expression and down-regulating Akt activity in breast cancer cells. Cancer Res. 2007; 67:5083-9. | Article | PubMed Abstract | PubMed FullText

7. Hoenerhoff MJ, Chu I, Barkan D, Liu ZY, Datta S, Dimri GP and Green JE. BMI1 cooperates with H-RAS to induce an aggressive breast cancer phenotype with brain metastases. Oncogene. 2009; 28:3022-32. | Article | PubMed Abstract | PubMed FullText

8. Itahana K, Zou Y, Itahana Y, Martinez JL, Beausejour C, Jacobs JJ, Van Lohuizen M, Band V, Campisi J and Dimri GP. Control of the replicative life span of human fibroblasts by p16 and the polycomb protein Bmi-1. Mol Cell Biol. 2003; 23:389-401. | Article | PubMed Abstract | PubMed FullText

9. Kim JH, Yoon SY, Jeong SH, Kim SY, Moon SK, Joo JH, Lee Y, Choe IS and Kim JW. Overexpression of Bmi-1 oncoprotein correlates with axillary lymph node metastases in invasive ductal breast cancer. Breast. 2004; 13:383-8. | Article | PubMed

10. Kleer CG, Cao Q, Varambally S, Shen R, Ota I, Tomlins SA, Ghosh D, Sewalt RG, Otte AP, Hayes DF, Sabel MS, Livant D, Weiss SJ, Rubin MA and Chinnaiyan AM. EZH2 is a marker of aggressive breast cancer and promotes neoplastic transformation of breast epithelial cells. Proc Natl Acad Sci U S A. 2003; 100:11606-11. | Article | PubMed Abstract | PubMed FullText

11. Kuzmichev A, Jenuwein T, Tempst $P$ and Reinberg D. Different EZH2containing complexes target methylation of histone $\mathrm{H} 1$ or nucleosomal histone H3. Mol Cell. 2004; 14:183-93. | Article | PubMed

12. LaJeunesse $D$ and Shearn $A$. Trans-regulation of thoracic homeotic selector genes of the Antennapedia and bithorax complexes by the trithorax group genes: absent, small, and homeotic discs 1 and 2. Mech Dev. 1995; 53:123-39. | Article | PubMed

13. Lozzio $C B$ and Lozzio $B B$. Human chronic myelogenous leukemia cell-line with positive Philadelphia chromosome. Blood. 1975; 45:321-34. | Article | PubMed

14. Park JI, Kim SW, Lyons JP, Ji H, Nguyen TT, Cho K, Barton MC, Deroo T, Vleminckx K, Moon RT and McCrea PD. Kaiso/p120-catenin and TCF/ beta-catenin complexes coordinately regulate canonical Wnt gene targets. Dev Cell. 2005; 8:843-54. | Article | PubMed

15. Pizzatti L, Binato R, Cofre J, Gomes BE, Dobbin J, Haussmann ME, D'Azambuja D, Bouzas LF and Abdelhay E. SUZ12 is a candidate target of the non-canonical WNT pathway in the progression of chronic myeloid leukemia. Genes Chromosomes Cancer. 2010; 49:107-18. | Article | PubMed

16. Shearn A. The ash-1, ash-2 and trithorax genes of Drosophila melanogaster are functionally related. Genetics. 1989; 121:517-25. I Article | PubMed Abstract | PubMed FullText

17. Soubry A, van Hengel J, Parthoens E, Colpaert C, Van Marck E, Waltregny $D$, Reynolds $A B$ and van Roy F. Expression and nuclear location of the transcriptional repressor Kaiso is regulated by the tumor microenvironment. Cancer Res. 2005; 65:2224-33. | Article | PubMed

18. Sparmann A and van Lohuizen M. Polycomb silencers control cell fate, development and cancer. Nat Rev Cancer. 2006; 6:846-56. | Article | PubMed

19. Wang W, Qin JJ, Voruganti S, Nag S, Zhou J and Zhang R. Polycomb Group (PcG) Proteins and Human Cancers: Multifaceted Functions and Therapeutic Implications. Med Res Rev. 2015; 35:1220-67. | Article | PubMed Abstract I PubMed FullText

20. Varambally S, Dhanasekaran SM, Zhou M, Barrette TR, Kumar-Sinha C, Sanda MG, Ghosh D, Pienta KJ, Sewalt RG, Otte AP, Rubin MA and Chinnaiyan AM. The polycomb group protein EZH2 is involved in progression of prostate cancer. Nature. 2002; 419:624-9. | Article | PubMed

\section{Citation:}

Cofre J and Abdelhay E. A feedback loop that regulates the expression of polycomb group protein Suz12 via non-canonical WNT signaling pathway in blast crisis of chronic myeloid leukemia. Hematol Leuk. 2017; 5:1. http://dx.doi.org/10.7243/2052-434X-5-1 